\title{
APRENDIZAGEM ADULTA E TECNOLOGIA NA VIDA DA CLASSE OPERÁRIA*
}

NoelLa INVERNIZZi*

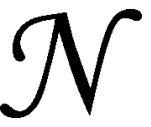

o interessante livro A prendizagem adulta e tecnologia na vida da classe operária, Peter Sawchuk apresenta-nos uma cuidadosa pesquisa sobre a aprendizagem da informática por operários industriais canadenses. Mostra-nos não apenas os processos através dos quais essa aprendizagem acontece, mas também como eles estão modelados pelas circunstâncias de trabalho e de vida dos trabalhadores.

Fazendo uma revisão da literatura, o autor revela as fraquezas das teorias convencionais sobre a aprendizagem adulta para entender a aprendizagem não-formal. Por exemplo, elas não conceituam de maneira adequada a interação entre os aspectos conscientes e os aspectos tácitos da aprendizagem, nem entre seus aspectos individuais e coletivos. Também não levam em conta o contexto político e econômico no qual a aprendizagem acontece. Mais ainda, tais teorias expressam e reproduzem um viés de classe ao enfatizar alguns aspectos da aprendizagem e ocultar outros.

Dado que o autor pretende analisar os processos de aprendizagem da informática realizados por trabalhadores industriais, processos que ocorrem predominantemente em âmbitos não-formais, ele constrói suas ferramentas analíticas a partir de outras fontes. Sawchuk retoma, sobretudo, as teorias socioculturais da aprendizagem, particularmente a activity theory e a situated learning theory. Para entender a relação entre experiência passada, aprendizagem presente e reprodução da vida operária, reconstrói criticamente o conceito de habitus de

\footnotetext{
* Resenha do livro de Peter H. Sawchuk, A dult learning and technology in working-class life (New York: Cambridge University Press, 2003).

** Pós-doutora pela Columbia University (Washington, EUA). E-mail: ni2105@ columbia.edu/ noela@ufpr.br
} 
Bourdieu, dando lugar ao conceito de habitus de aprendizagem da classe trabalhadora. Finalmente, ele faz uma conexão com Gramsci, trazendo sua noção de senso comum - mescla de ideologias e de perspectivas que emergem das experiências de vida da classe operária para analisar as idéias que os trabalhadores têm desenvolvido em relação a tecnologia.

As evidências empíricas provêm de 73 entrevistas por meio das quais 0 autor explorou os processos de aprendizagem na história de vida dos trabalhadores, assim como da observação etnográfica em âmbitos de aprendizagem nas fábricas, nos lares e nos sindicatos, outorgando particular atenção na observação da interação homem-computador. Os entrevistados são trabalhadores na indústria automobilística (na qual o próprio autor trabalhou, o que dá ao livro uma visão bem interiorizada, rica e compromissada, à Braverman) e na indústria química. A investigação também contém umas poucas entrevistas a altos executivos de empresas, realizadas com o objetivo de contrastar a visão desses e dos trabalhadores em relação à tecnologia e à alfabetização científica e que, efetivamente, revelam diferentes perspectivas de classe.

A investigação de Sawchuk mostra que os operários industriais têm construído vastas redes de aprendizagem da informática, fenômeno que tem sido pouco documentado e que não é captado por indicadores tais como número de computadores por domicílio. A pesquisa mostra, também, que tais práticas não podem ser apreciadas numa perspectiva cognitiva individual, nem nos moldes de uma relação pedagógica experto-novato. Pelo contrário, são práticas predominantemente coletivas e cooperativas, enraizadas na vida cotidiana, em condições materiais específicas e na cultura da classe operária. 0 autor aponta que "o panorama da aprendizagem da informática que surgiu das entrevistas era um de esferas de atividade superpostas e com propósitos múltiplos, nas quais só havia momentos isolados (...) que podiam ser considerados como instâncias de aprendizagem no sentido convencional" (p. 97). Mais ainda, "a aprendizagem da informática pela classe operária está a miúde embutida em atividades que não têm 0 propósito da aprendizagem per se" (p. 122).

Em vários momentos, o autor corre 0 risco de cair numa visão romântica da aprendizagem tácita ao descrever os recursos, sempre árduos, encontrados por muitos trabalhadores para aprender e, inclusi- 
ve, tornar-se "expertos" em informática. Porém, isso não chega a acontecer. 0 livro transmite, sem dúvida, emoção ao relatar a luta constante desses trabalhadores por atualizar seus conhecimentos frente à ameaça latente de perder o emprego por falta de alfabetização tecnológica - uma noção que tem se difundido no sentido comum operário. 0 trabalho de Sawchuk nos mostra também que esses processos de aprendizagem se defrontam com restrições materiais contínuas, tais como as dificuldades para adquirir um computador e mantê-lo atualizado; dispor de condições durante o tempo de trabalho para dominar softwares, no contexto da divisão do trabalho fabril, das pressões impostas pelo processo produtivo e as regulamentações fabris; a necessidade de utilizar o tempo livre, o tempo familiar para correr atrás do conhecimento, o qual, por sua vez, gera diferenciações de gênero importantes. Todas essas restrições fazem com que o processo de aprendizagem esteja sempre ameaçado pela fragmentação. E essa fragmentação do conhecimento é uma característica específica dada pelas condições de classe, como também o é o seu caráter coletivo e cooperativo.

O livro conclui com algumas recomendações políticas. Elas partem da constatação, feita durante a pesquisa, de que a chamada sociedade do conhecimento não abriu mão, nem no âmbito fabril nem na vida social em geral, da distribuição hierárquica do conhecimento e da informação. A questão de classe, assim, não só manifesta-se nas desigualdades no acesso e na qualidade da educação formal. Também está presente nos processos informais de aprendizagem que ocorrem na vida cotidiana. Para os grupos subordinados, continua sendo necessário reivindicar melhores condições no âmbito da educação formal, à qual o autor outorga o papel fundamental de acentuar, dar forma e ligar o amplo e difuso conhecimento que se obtém cotidianamente em todos os âmbitos da vida. Todavia, a educação formal não basta. Segundo o autor, é preciso fortalecer as redes de conhecimento informal. Para tanto, colocam-se outros desafios, tais como a necessidade de maior participação democrática no processo de pesquisa e desenvolvimento da tecnologia; a necessidade de criar condições para o desenvolvimento das redes de aprendizagem no trabalho, condições que requerem maior estabilidade no emprego; e a necessidade de desenvolver novos enfoques na educação de grupos subordinados, promovendo a transformação do senso comum no que Gramsci chamou o "bom senso". 